\title{
The Influence of Founder Type on Charter School Structures and Operations
}

\author{
JEFFREY R. HENIG \\ Teachers College, Columbia University \\ THOMAS T. HOLYOKE \\ Hastings College \\ HEATH BROWN \\ George Washington University \\ NATALIE LACIRENO-PAQUET \\ University of Massachusetts, Boston
}

\begin{abstract}
Much of the literature on charter schools treats them as an undifferentiated mass. Here we present and test a typology of charter schools that is grounded in the norms, traditions, and perspectives of the founding organization or organizers. We suggest that there are two broad categories of charter foundersthose who are more mission oriented and those who are more market orientedand we further disaggregate these categories into subtypes. Using data from a multistate survey of charter schools, we test the typology by examining charter school behaviors related to choosing a theme and targeting, deciding on the size and grade configuration, and marketing and market research behavior.
\end{abstract}

Charter schools are a rapidly disseminating policy innovation with import both to education policy and to broader theories regarding both the actual and ideal boundaries separating the public and private sectors. The first charter school law was passed by Minnesota in 1991; just six years later there were 428 schools in operation, and by the 2003-4 school year there were 2,996 charter schools in 41 states (Allen and Marcucio 2004; Anderson et al. 2000). Proponents portray them as a model for marrying the efficiency, responsiveness, and innovation associated with markets to the broader collective interests, social justice concerns, and democratic accountability associated with government and civil society (Finn et al. 2000).

At this point, however, the notion that charter schools will selectively combine the best aspects of government, market, and the nonprofit community

American Journal of Education 111 (August 2005)

(C) 2005 by The University of Chicago. All rights reserved.

0195-6744/2005/11104-0004\$05.00

AUGUST 2005 


\section{Influence of Founder Type on Charter Schools}

is at best an untested premise. The empirical literature on how charter schools behave is growing, but it is still in its infancy. Several studies have examined whether charter schools respond to market signals by weeding out high-need and low-status students (Lacireno-Paquet 2004; Lacireno-Paquet et al. 2002; Wong and Shen 2000; Zollers and Ramanathan 1998), others have begun to look at their governance structures (Miron and Nelson 2002; Vergari 2002), still others have begun analyzing performance outcomes (Miron and Nelson 2002), and finally a few have attempted to gauge the competitive effects of charter schools on conventional public school systems (Hess et al. 2001; Teske et al. 2000). On top of these works, there are numerous and polarizing anecdotal reports, some detailing heartwarming accounts about dynamic and effective charter schools turning around the lives of students, while others tell horror stories about amateurish and short-lived efforts, fiscal shenanigans, inflated promises, and dismal test results. More systematic analyses have tended to suggest that charter schools look pretty much like conventional public schools, at least as far as curriculum, student composition, and performance are concerned.

One explanation for this pattern of polarized and inconsistent findings is that "charter school" is an umbrella term that can apply to a wide range of organizations differing in mission, background, and behavioral tendencies. In keeping with this, recent studies have begun to unearth systematic differences across dichotomous categories of charter schools. Some find differences, for example, based on whether or not charter schools are associated with for-profit educational management organizations (EMOs; e.g., Brown et al. 2004; Bulkley 2001, 2002; Lacireno-Paquet 2004; Lacireno-Paquet et al. 2002; Miron and Nelson 2002). Others have found sharp differences between charter schools started de nova and long-standing public schools that converted to charter schools (Fuller et al. 2003; Zimmer et al. 2003). But almost no effort has been made to probe for finer distinctions within these categories, and there have been only limited efforts to

JEFFREY R. HENIG is professor of political science and education at Teachers College, Columbia University. His most recent book, coedited with Wilbur Rich, is Mayors in the Middle: Politics, Race, and Mayoral Control of Urban Schools (Princeton, NJ: Princeton University Press, 2004). Thomas T. Holyoke is assistant professor in the Department of Political Science at Hastings College. His research specialties include collective action and the influence of private organized interests on state, local, and national policy making. HEATH BROWN is a doctoral candidate in public policy at the George Washington University. NATAlie Lacireno-PaQuet is an assistant professor in the Leadership in Urban Schools Program at the University of Massachusetts, Boston, where she teaches research methods and education policy. 
link these typologies to broader theoretical foundations about organizational differentiation, behavior, and change.

This article seeks to inform deliberation about charter schools and the boundary between public and private by exploring variation in internal school characteristics and by offering a typology of charter schools that distinguishes broadly between those that, by virtue of their experience, norms, and organizational structures, might be assumed to be more oriented toward markets and those assumed to set a direction more in line with a purposive, collective, and philanthropic mission. We also distinguish within the mission-oriented sector those whose missions are more likely to be defined by norms and ideas associated with educational professionalism, provision of social services, and grassroots visions tied to community and parental involvement as well as local economic development. Drawing on a survey of charter schools operating in Arizona, Michigan, Pennsylvania, and the District of Columbia, we then test the hypothesis that organizational type makes a difference in charter school behavior in terms of how schools define, pursue, and respond to their intended consumers.

\section{A Typology of Charter Schools Based on Organizational Origin}

Charter schooling is just one example of a seemingly growing tendency of government to experiment with variations in public-private delivery mechanisms for providing public services (Henig et al. 2003; Kettl 1993; Salamon 1987, 1995). The dominant rationale has been the desire to exploit the greater flexibility, responsiveness, and efficiency presumably exhibited by private firms subject to market dynamics (Savas 2000). This privatization movement is frequently traced in the United States to the Reagan Era, a period during which the celebration of the market as an alternative to government framed the national policy agenda (Linowes 1988). But experimentation with alternative private sector delivery mechanisms has deeper historical and wider theoretical roots than the promarket vision that has dominated contemporary political discourse.

Earlier efforts at harnessing private organizations to public agendas shared with contemporary privatization initiatives a desire for flexibility, responsiveness, and efficiency; the favored vehicles, however, typically were not for-profit corporations but community-based social service agencies that existed more for carrying out missions defined in terms of the betterment of a needy population or neighborhood than making money. State and local governments were a major source of funding for these private voluntary agencies, which were working with immigrant and poor populations in some large cities even before the turn of the twentieth century (Katz 1996; Salamon 1995). Although

AUGUST 2005 


\section{Influence of Founder Type on Charter Schools}

the War on Poverty of the 1960s has come to symbolize "big government" in some strains of American folklore, its premier programs relied heavily on partnerships between national government and local community-based organizations as vehicles for planning and delivering services (Smith and Lipsky 1993). Rather than responsiveness to external signals of supply and demand, this form of privatization was premised on the belief that the social good could be best achieved by tapping into the intense internal commitment of such organizations' leaders and supporters. Consequently, the behavior of these nonprofits, both in terms of internal organization and external delivery of services, often manifested in ways quite different from the publicly contracted for-profits of the 1980s even though both were charged with similar public service tasks.

There are good reasons to expect nonprofit and for-profit organizations to behave in different ways. Sociologists (e.g., DiMaggio and Anheier 1990) and some political scientists (e.g., Wilson 1973) have long recognized that organizations driven by "purposive" or "solidary" incentives emphasize the collective good over the material gain of individuals and that such differences have a range of important behavioral consequences. As illustrated in figure 1, the nonprofit and for-profit sectors can be seen to comprise a different set of actors oriented around different incentives, norms, and problem definitions, bringing to bear a distinct set of resources. Moreover, empirical comparisons of nonprofit and for-profit behaviors in arenas in which they cohabitate - such as health care, nursing homes, and child care-provide evidence that nonprofits at least sometimes appear to make systematically different choices than forprofits in staffing, pricing, screening of customers, and selection among alternative delivery mechanisms (see Bushouse 1999; Mark 1995, 1998; Weisbrod 1998).

In the case of charter schools, recent studies have found evidence of differences between those rooted more in the social service, nonprofit sector and those with more corporate ties. Lacireno-Paquet et al. (2002) and Miron and Nelson (2002), for example, indicate that market-oriented charters - those operated by for-profit EMOs - serve a somewhat less disadvantaged set of students than do other charter schools. However, Lacireno-Paquet (2004) finds differences even within the EMO category, with schools managed by large, multistate firms enrolling similar percentages of low-income and minority students as more mission-oriented schools, but with schools operated by small (fewer than 10 schools) EMOs enrolling lower percentages of minority students. Henig and MacDonald (2002) found that in the District of Columbia, marketoriented charter schools were more likely to locate in neighborhoods with high home ownership rates and less likely to locate where there were high concentrations of Hispanic residents. Furthermore, Brown et al. (2004) found that charter schools initially launched by EMOs are larger and less likely to 
Henig et al.

\begin{tabular}{c|c|c} 
Market & Mission \\
\hline $\begin{array}{c}\text { Consumers and for- } \\
\text { profit firms }\end{array}$ & Central Actors & $\begin{array}{c}\text { Donors, nonprofit } \\
\text { delivery } \\
\text { organzations, } \\
\text { clients }\end{array}$ \\
\hline $\begin{array}{c}\text { Material benefits; } \\
\text { profit } \\
\text { maximizations; self- } \\
\text { interest }\end{array}$ & Incentives & Purposive, altruistic \\
\hline $\begin{array}{c}\text { Flexibility; } \\
\text { responsiveness; } \\
\text { mobility; the } \\
\text { "customer" is } \\
\text { always right }\end{array}$ & Dominant Norms & $\begin{array}{c}\text { Helping; } \\
\text { voluntarism; } \\
\text { consistency of } \\
\text { purpose; loyalty }\end{array}$ \\
\hline $\begin{array}{c}\text { How to satisfy } \\
\text { consumers' desires } \\
\text { most efficiently }\end{array}$ & Problem Definition & $\begin{array}{c}\text { How to meet the } \\
\text { needs of clients } \\
\text { while maintaining } \\
\text { the allegiance of } \\
\text { patrons }\end{array}$ \\
\hline $\begin{array}{c}\text { Capital and } \\
\text { purchasing power; } \\
\text { entrepreneurial } \\
\text { skill; adaptibility }\end{array}$ & Key Resources & $\begin{array}{c}\text { Intensity and depth } \\
\text { of commitment; co- } \\
\text { production; } \\
\text { reputation for doing } \\
\text { good }\end{array}$ \\
\hline
\end{tabular}

FIG. 1.-Market vs. mission

delegate to the school decisions regarding curriculum, testing, discipline, and facilities.

As nonprofit entities are rooted more in civil society than competitive markets, we expect such mission-oriented charter schools to share some behavioral tendencies that distinguish them from those spawned by for-profit corporate sponsors. But we do not mean to treat mission-oriented nonprofits, including charter schools sponsored by nonprofits, as a monolithic bloc exhibiting uniform behavior. Like the broader privatization movement with which it is associated, the charter school phenomenon is more diverse in membership and motivation than the simple for-profit versus nonprofit dichotomy implies. Many charter schools currently operating in the United States have been launched by teachers animated by particular pedagogical visions, by parents driven by dissatisfaction with bureaucratic rules and regulations, or by local

AUGUST 2005 


\section{Influence of Founder Type on Charter Schools}

businesses that see school reform as a key to stronger economic development or to training potential future workers. Because such organizations tend to draw their ideologies and staff from distinctly different cultures, the result can be a variety of beliefs, norms, and missions that all happen to find the nonprofit form of organization as the most beneficial. As a result, not only do we expect nonprofits as a whole to behave in ways distinctly different from for-profits, but within the broad category of nonprofits we anticipate finding systematic variations in behavior.

Specifically, among the nonprofit organizations that have responded to the opportunity to launch charter schools, we can identify several distinct types: "social service," or "helping," organizations are oriented around a mission of providing help to needy populations. This category, which includes organizations that run food pantries, provide job training, work with delinquent youth, and so on, is perhaps what most people have in mind when they refer generally to the nonprofit or voluntary sector. Some long-standing social service agencies were quick to recognize that charter school legislation provided opportunities for them to expand the range of services they could offer to clients and, simultaneously, to open up a major new source of funding. For example, the Next Step charter school in Washington, DC, was established by a nonprofit with a larger mission of providing counseling and support services to single mothers and young adults who have dropped out of public education. The school serves as a means of training young women, most of whom are Latina, in the skills necessary for service sector jobs, how to pass the graduation equivalent degree, and even how to improve their English.

Because social service organizations have clearly defined and highly needy populations to whom they are committed, we expect the charter schools they launch to focus on populations defined by particular categories of need and to put more emphasis on effective provision of services than on growth and expansion. Because they and their members are accustomed to relying on philanthropy and government contracts as revenue sources, we might also expect them to be less attuned to conventional marketing strategies, to be more likely to partner with various foundations or other nonprofits that provide additional support, and to invest more resources in monitoring developments within the public sector than in surveying potential new clients or the activities of competitor schools. Because students enrolled in such charters are regarded as more costly and difficult to educate, programs launched by these organizations are less likely to be seen as a competitive threat by the conventional school district (indeed, they may be welcomed as a source of relief), and therefore we might expect them to be more likely to interact with and cooperate with traditional public schools than would other types of missionoriented or for-profit charter schools.

By design, "professionally defined organizations" such as the American Bar

\section{$492 \quad$ American Journal of Education}


Henig et al.

Association or the American Medical Association seek to embody the values, body of knowledge, and preferred practices of a profession in the services they produce. ${ }^{1}$ Educators' claim to professional status has been more contested than these "higher status" occupations, so perhaps for this reason their formal collective organizations - such as the National Education Association and the American Federation of Teachers - have straddled the boundary between professional association and labor union and have invested considerable political capital in traditional systems of public education. As a result, though teacher unions have occasionally launched charter schools, the educators who have done so are more likely to have acted individually, or as a small collection of individuals, animated by a shared vision of what good schooling entails. Examples of these schools would be those launched by teachers and administrators who are tired of fighting school district bureaucracy and wish to implement new programs or curricula they believe would work for particular types of students. These might, for example, include teachers who want to implement expeditionary learning in a middle school.

Because they are invested in the notion that they possess a special expertise that legitimates particular ways of doing things (a "one right way"), we might expect charter schools launched by education professionals to be less likely to adapt and change in response to market signals. But unlike charter schools affiliated with social service nonprofits - because charter schools launched by education professionals typically claim that key decisions require the exercise of "professional judgment," of which they are the sole or primary arbiterswe might expect such organizations to be less likely to engage in partnerships that entail a sacrifice in their autonomy.

"Grassroots community-based organizations" are formed to pursue the interests of a geographically defined group of citizens who share certain interests and values relating to ethnicity, race, housing tenure, and socioeconomic class. Typically these are less formally structured than social service or professional organizations and may even be et al., single-issue (e.g., "stop the highway") groups that dissipate once their goals are achieved, though some may be more multi-issue (community betterment) in their scope, acting as community institutions with a small but permanent staff (Berry 1999). In fact, these types of community-based organizations primarily tend to adopt more formal structures when doing so facilitates a desired ability on their part to pursue grants and contracts or play official or advisory roles in governmental proceedings.

Grassroots community charter schools started by groups of parents or neighborhood leaders who are discontented with the traditional school system might be linguistically, culturally, or ethnically oriented schools, such as those focusing on Armenian culture and language or Afrocentric schools. Fuller et al. (2004, 93-94) characterize the motivation of some of these grassroots charter initiators as a "non-modern return to local cultural forms and particular ways of raising

AUGUST 2005 


\section{Influence of Founder Type on Charter Schools}

children" and suggest that such schools will make very different commitments to equity and fairness than those tied to for-profit corporations and more professionally oriented mission-driven charters; because their vision can be shaped by very localized values, they also may make very different decisions from one another.

Because their mission is linked to small and relatively well-defined groups of individuals, we expect charter schools founded by grassroots communityoriented organizations to also be relatively small, less likely to advertise widely, and less likely to have plans to expand. Because they are often steeped in norms about internal democratic decision making, we anticipate that charter schools launched by grassroots organizations will be more likely than others to adopt (eventually if not immediately) a comprehensive $\mathrm{K}-12$ grade structure; parents within elementary-level charter schools frequently want their children to complete their secondary education there rather than being forced to return to the traditional district option, and grassroots-initiated charter schools are less likely than others to be able to resist such pressure.

Finally, some nonprofit charter schools are founded by "local business and economic development organizations," such as chambers of commerce or downtown business associations. Of all the types of charter schools we discuss, this one seems least likely to differ in orientation and behavior from for-profit EMOs and, by extension, to differ considerably from other mission-oriented schools. After all, though working for a nonprofit, the leaders of local business groups often come from the market sector, and we would expect them to draw on the norms and perceptions that led to their successes in that arena as they approach the challenge of forming and providing guidance to charter schools. Nonetheless, there are at least two reasons why charter schools launched by such organizations may behave more like mission-oriented than profit-oriented ones. First, what typically motivates local business organizations to sponsor charter schools is not profit - a private and material good - but the long-term economic health of the immediate community, a conventional collective good (Peterson 1981). ${ }^{2}$ In pursuit of the city's economic interest, such organizations would tend not to seek profits from operating schools but to operate them with goals of improving the local labor pool and raising test scores so as to improve the city's overall image and attractiveness to residents, businesses, and investors. A second reason that charter schools founded by such organizations may tend to behave more like other mission-oriented than profitoriented organizations is that the local business leaders who are the members of the chamber or business association may have only a very arms' length relationship with the charter school itself. After helping to set broad goals, local business organizations often hire conventional educators or others with 
nonprofit and social service backgrounds to manage the school on a day-today basis.

Yet, compared with other mission-oriented groups we would expect charter schools launched by these nonprofits to be more businesslike and efficiencyoriented in their approach. We expect them to focus more on providing job skills to potential entry-level workers; thus, compared with others, these charter schools might be more likely to operate at the secondary school level and to organize themselves around a career or vocational theme. We expect them to be less likely to target populations whose special needs make them potentially less desirable as employees, for example, those with physical or emotional disabilities or those with criminal or delinquency records. These operators might be more likely to focus on vocational training and skill-based learning oriented to the needs of local businesses. For instance, in the District of Columbia, one local hotel firm has helped operate a school oriented toward the hospitality industry.

Drawing on this discussion, we now state a testable hypothesis regarding charter schools' behavior, though with a qualification. Specifically, given fundamental differences in the motivations of for-profit- and nonprofit-affiliated charter schools, we argue that the former are more likely to alter internal organizational forms and marketing strategies to attract ever greater numbers of students in order to receive the benefits of economies of scale and to turn a profit. Charter schools established by, or at least affiliated with, nonprofits, by contrast, are more likely to strive for quality over quantity and serve smaller populations, especially populations with particular common needs, such as racial minorities or juvenile offenders. Furthermore, when confronted with problems such as budgetary concerns, rather than alter organizational behavior and goals, such schools are more likely to try to alter external factors, for example, by applying for more philanthropic support or by advocating for greater levels of government financing. In other words, we expect there to be a systematic divergence in the behavior of for-profit- and nonprofitoriented charter schools.

Yet we have also argued that within the nonprofit charter school community there is a wide variety of motives preventing us from making unqualified predictions as to what type of behavior we would expect from these types of charter schools. If true, then there is a limit to what we can hope to uncover with empirical data analysis by making a simple binary distinction between for-profit and nonprofit charter schools. Rather, we will be required to extend any typology used in any statistical analysis to subcategories reflecting the distinctions within the nonprofit category laid out above to see if systematic differences in behavior occur at that level.

AUGUST 2005 


\section{Influence of Founder Type on Charter Schools}

\section{A Rival Hypothesis: Why We Might Expect Convergence}

A key unresolved question is whether the differences commonly associated with market- versus mission-orientation are fundamental - meaning that they are hardwired into their differences in formal legal status, recruitment patterns, and worker socialization strategies - or contingent on the different service niches they typically occupy. More simply expressed, to what extent are differences in behavior a product of environment rather than the preferences of organizational founders and leaders? This question is moot when nonprofits and for-profits do fundamentally different things, but it comes into sharp relief when they appear to go head-to-head, as in the charter school arena, and in other arenas such as hospitals, nursing homes, and day cares. If charter school behavior is largely driven by the norms, problem definitions, and institutional characteristics of the founding organization, we expect to find differences among them in the kinds of decisions and behaviors they exhibit. If internal differences in origin are overwhelmed by common elements in their task and operating environment-including the resources they can attract, the competition they face, and the regulatory context they face - we might reasonably anticipate convergence in behavior. Mission-oriented organizations, for example, might begin to behave like for-profit organizations, abandoning visions about maintaining small scale or exclusively serving high-need populations because of necessary pressures to attend to the "bottom line." Profit-oriented EMOs, for their part, might find that they must borrow equity-oriented strategies associated with social service and community-based organizations in order to garner favor from foundations and politically sensitive chartering agencies or to adopt practices associated with professional educators in order to fit parental preconceptions of what a school ought to look like.

Data and Methods

The data we use to test our hypothesis are drawn from a survey sent to charter schools in three states, Arizona, Michigan, and Pennsylvania, and the District of Columbia. The survey is part of a larger study of charter schools; we selected states that had charter schools in operation for several years in order to have a large enough sample and for the norms and behaviors of the schools to be established; each had its charter school law in place by 1997, and each had charter schools operating by 1999. Because we were interested in how schools with close ties to for-profit firms might differ from more community-oriented charter schools with strong nonprofit backgrounds, we limited our focus to states containing school districts in which at least one of the major for-profit charter management firms had a presence. In addition, among those states

\section{American Journal of Education}


Henig et al.

that met the preceding criteria, we sought to maximize variation in state political ideology and racial diversity, as operationalized by Erickson et al. (1993) and Hero (1998), respectively. This purposeful selection of states means that these states cannot be assumed to be representative of all states with charter schools. As a demographically and politically heterogeneous group with relatively established and organizationally diverse charter school populations, these states are good windows into how the movement may mature over time (Brown et al. 2004).

The survey was sent to the principal or director of every charter school in each state in January 2002. A list of school addresses was drawn from state and national databases of schools and school districts. We included only schools that were open as of the 1999-2000 school year and verified that schools opened before 1999-2000 were still in operation whenever possible. Basic descriptive information about the school was collected along with responses to closed-ended questions regarding the school's founding, operations and recruitment strategies, and relations with government and support organizations. We received a total of 270 surveys for a response rate of 35 percent. This response rate is relatively good when measured against the track record of other efforts to get information on charter schools, which are often quite small, often quite overwhelmed, and sometimes quite suspicious of outsiders. By comparison, the Center for Education Reform, a highly visible organization that takes a pro-charter school position, reports a response rate of just over 20 percent in its 2002 Annual Survey of Charter Schools (Center for Education Reform 2002). Comparison with comparable dimensions to charter schools in the 1999-2000 Schools and Staffing Survey (SASS), conducted by the U.S. Department of Education, provides some reassurance that our sample is representative. $^{3}$

\section{Distribution of Schools by Type of Founder}

Before presenting our multivariate analysis, we discuss the distribution of responding schools within the categories of the typology. In the school survey, we asked respondents: "Thinking about the individuals and organizations that played central roles in starting your charter school, please indicate which of the following best apply." We think that it is important to look at both the origin and subsequent partnering behavior of charter schools, but in this analysis our central interest is in the kinds of organizations that spawned the school. Charter schools launched by strong and focused mission-oriented organizations may subsequently contract with for-profit EMOs without relinquishing their founding vision. Or, they may ally with EMOs and lose key battles to define the school's direction. Wohlstetter et al. (2004) provide a good

AUGUST 2005 


\section{Influence of Founder Type on Charter Schools}

discussion of the incentives and facilitating conditions for alliance formation by charter schools. We consider it to be an open but critical question whether, and under what conditions, the values and orientations of the founding organizations either set and maintain the course or are subsequently rendered moot as charter schools respond to day-to-day demands.

Based on their responses, we assigned each charter school to one of seven categories mirroring the organizational types discussed above. ${ }^{4}$ Table 1 summarizes basic descriptive information about the types of charter schools as classified by founder characteristics. Seventeen percent of the responding schools were founded by an EMO, either on their own (10.7 percent) or operating along with other organizations (6.3 percent). The remainder of schools, which we categorize as broadly "mission-oriented," include those formed by educators (40.3 percent), by social service or nonprofit organizations (13.4 percent), by community and parent groups (9.1 percent), by local business groups (6.7 percent), and those that checked more than one option not including an EMO (13.4 percent). ${ }^{5}$ The seven types of charter schools are not evenly distributed over the four jurisdictions. Michigan by far had the largest concentration of EMO-related schools (over one-third of the Michigan schools indicated they had an EMO among their founders), followed by Pennsylvania (14 percent), Arizona (10 percent), and the District of Columbia (5 percent). ${ }^{6}$ Former educators were important founding groups in all of the jurisdictions, but especially in Arizona, where they constitute almost 55 percent of the responding schools. The District of Columbia had the highest concentration of charter schools founded by social service/nonprofit organizations (30 percent).

There are differences, too, although less sharply edged, in the degree to which different types of schools locate in cities, suburbs, and rural areas. ${ }^{7}$ Overall, most charter schools in our sample are found in central cities, a tendency particularly evident for those founded by local business groups or social service agencies. Educators and EMOs appear more likely than others to start charter schools in the suburbs. Of the seven types of charter founders, only parent- and community-based groups have a significant presence in rural areas.

Some observers have suggested that the first types of operators to enter the charter industry would be those with missionary and altruistic goals, followed later by those with profit-oriented ambitions (Solomon et al. 1999), and our findings regarding the age of existing charter schools appear to bear that out. Schools founded by community-based organizations, parents, or social service agencies tend to have been in operation for about four and one-half years in January 2002, when we conducted our survey. The newest entrants, those founded solely by EMOs, came onto the scene, on average, more than a year later. 


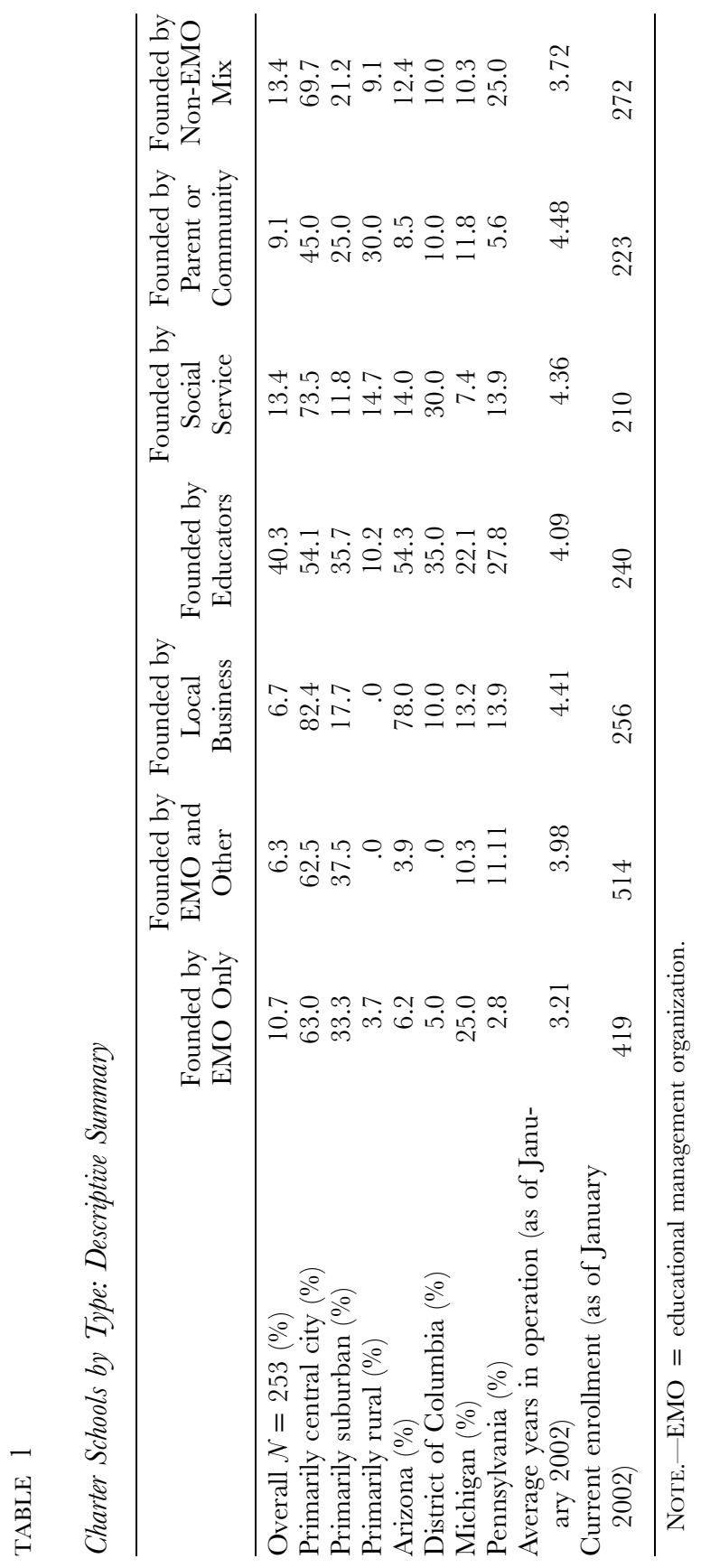

This content downloaded from 129.008.122.086 on September 01, 2016 14:09:42 PM 


\section{Influence of Founder Type on Charter Schools}

Results

To operationalize our competing hypotheses, we state the following empirical questions: Do the origins of a charter school make a difference in the types of decisions it makes? Do charter schools founded by EMOs behave more in the manner that economic theories project for profit-maximizing firms? Are mission-oriented charter schools less aggressive about marketing themselves or monitoring the activities of competitors? Do charter schools founded by educators make different decisions about who to target or having a theme than those founded by parents and community-based organizations? In the analysis below we estimate statistical models predicting different types of decisions that charter schools make in three categories: (1) theme and targeting, (2) scale of operations, and (3) marketing and market research.

\section{Theme and Target Population}

Two of the most important questions a charter school founder makes at startup are whether to feature a curricular "theme" and whether to target special populations of students, such as those at risk or teen parents. Decisions about these establish key parameters that in turn should affect the size, location, teacher recruitment and development needs, grade configurations, and even the kind of facility that will be needed. Schools that offer a general curriculum aimed at a "typical" student have a larger potential audience but may face particular challenges in creating an identity compelling enough to entice students.

If founding organizational traditions and norms matter, then we expect charter schools founded by educational professionals and parent groups to be the least likely to engage in curricular or student niche approaches: educators because they have training and experience in offering a general education (they would prefer to compete based on quality of service rather than product differentiation) and parent-community groups because their orientation is often around a specific and spatially defined set of families. More market-oriented, EMO-associated schools would be most likely to aim for the median student, although emphasizing a fairly broad theme might appeal as a marketing tool; they would be relatively unlikely to target a niche population unless it was one that had a particularly favorable revenue-to-cost ratio. Schools with a social service background would define their audience around a high-need population. Local business groups might be most likely to adopt a particular theme, tied to vocational or technical skills.

\section{$500 \quad$ American Journal of Education}


Henig et al.

Table 2 provides some descriptive information about charter schools' reliance on themes and targeting. We asked schools the following questions:

Does your school target a particular type of student (e.g., at-risk, special needs, gifted, juvenile offenders)?

Does your school's curriculum focus on a particular theme (e.g., character education, public policy, cultural heritage, technology, vocational, service industry)?

Schools that responded "yes" were asked to specify their target population or theme. In this analysis, without multivariate controls, EMO-founded or EMOcofounded schools do appear to be less likely to target a particular student group. Fewer than one in five of EMO-related charters indicated that they targeted a particular type of student, compared with just under one in three of all other types. ${ }^{8}$ Another way of saying this is that they appear more likely to aim their product at the general population, or at the median student; this is something that is certainly consistent with what one might expect of a market-oriented organization seeking to position itself where demand is likely to be greatest. Despite many analysts' concern that charter schools might systematically target the most advantaged students (Fiske and Ladd 2000; Kahlenberg 2001; Rothstein 1998), more than half of all the schools that said that they did target a group indicated that they targeted at-risk students. Overall, social-service-initiated charter schools are much more likely than others to engage in student targeting, and their target audience is almost always students with high needs. Parent- and community-initiated schools are the least likely to target specific student populations, consistent with our expectation that they would rely on spatially defined community to define their clientele. None of the parent- and community-based schools that responded to our survey indicated that they targeted at-risk youth.

Charter schools in our sample were twice as likely to say that they emphasized a curricular theme as they were to identify a target student group (just fewer than two out of three do so overall). Emphasizing a theme was most common among community-based and local-business-originated charters and least common among those initiated by social service or nonprofit groups. Community- and local-business-based schools differed, though, in the type of theme they emphasized, with business tending to focus on career- or tradespecific themes and community- or parent-based schools more likely to emphasize themes that have more to do with symbolically affirming community aspirations (college preparatory, character education) than filtering demand based on particular skills.

Table 3 presents a multivariate analysis to explain whether charter schools emphasize a theme (or not) and features two sets of independent variables. The "full" model includes separate dummy variables for each of the different types

AUGUST 2005 


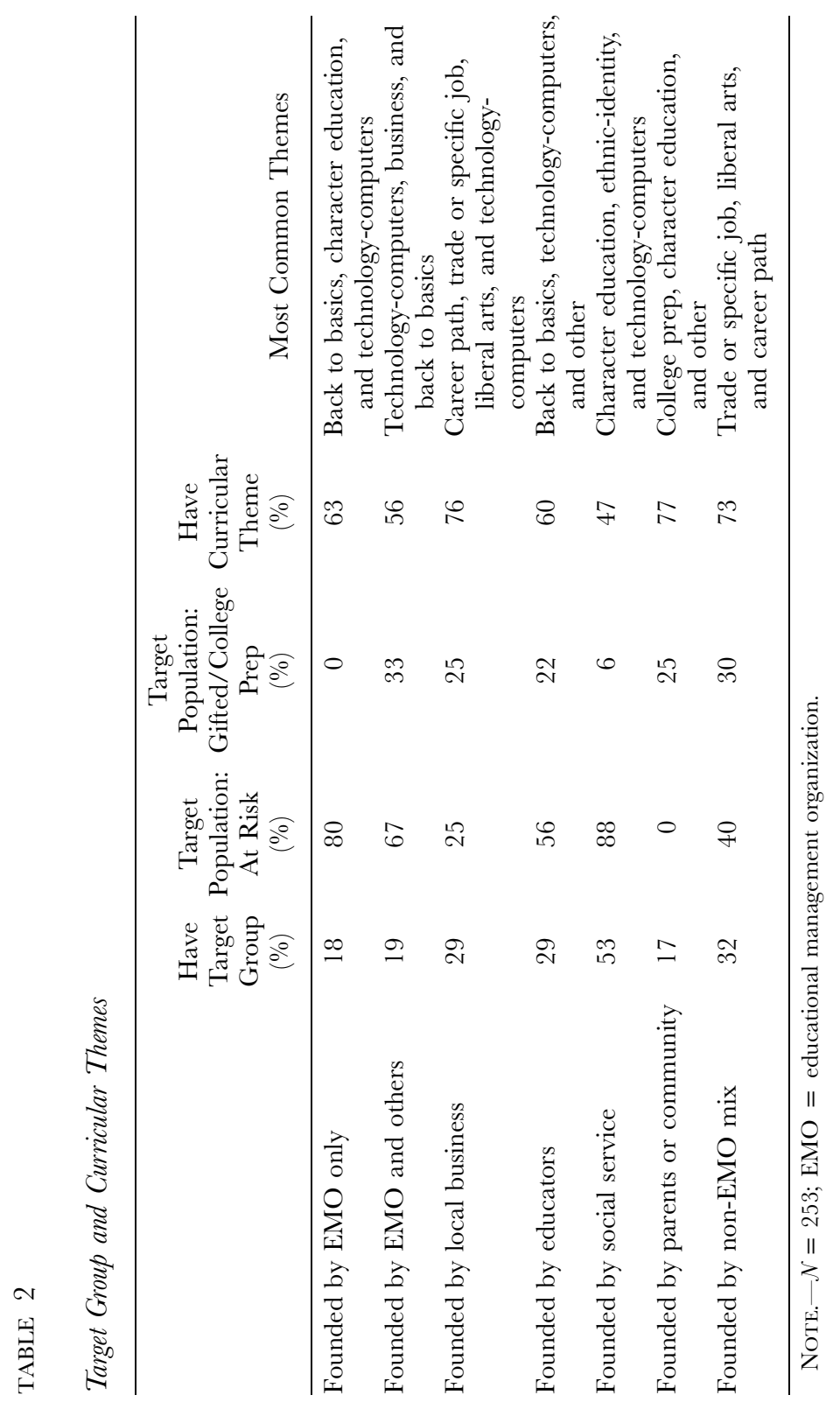

This content downloaded from 129.008.122.086 on September 01, 2016 14:09:42 PM 
Henig et al.

TABLE 3

Charter School Emphasizes a Theme (Logistic Regression with Robust SEs)

\begin{tabular}{lcc}
\hline Independent Variable & $\begin{array}{c}\text { Theme } \\
\text { Full Model }) \\
\text { Odds Ratio }\end{array}$ & $\begin{array}{c}\text { Theme } \\
\text { Reduced Model) } \\
\text { Odds Ratio }\end{array}$ \\
\hline Founded by local business & $5.48^{*}$ & $\ldots$ \\
Founded by educators & $(4.34)$ & $\ldots$ \\
Founded by a social service organization & $(.28$ & $\ldots$ \\
Founded by parents or community & .91 & $\ldots$ \\
Founded by non-EMO mix & $(.51)$ & $\ldots$ \\
Founded by EMO mix & 2.43 & $\ldots$ \\
Founded by EMO only & $(1.72)$ & $\ldots$ \\
Initiated by EMO (alone or with others) & 3.21 & $\ldots$ \\
& $(1.98)$ & $\ldots$ \\
Age of the school & .85 & .82 \\
& $(.64)$ & $(.34)$ \\
Central city district & Reference & .91 \\
&.. & $(.07)$ \\
District enrollment & & 1.07 \\
& $(.90$ & $(.42)$ \\
Wald $\chi^{2}$ & 1.03 & 1.01 \\
& $(.41)$ & $(.13)$ \\
& 1.01 & 1.88
\end{tabular}

NoTE. $-\mathcal{N}=248 ;$ EMO $=$ educational management organization.

a The variable "district enrollment" is the natural log of district enrollment.

$* p<.05$.

of more mission-oriented charter schools (with EMO-only-initiated schools being the excluded category). The "reduced" model makes a simpler dichotomous distinction between charter schools that have an EMO among the founding organizations and those that do not. We also include as control variables central city location; the number of years that the school has been in operation; and, in order to control for demand for education services, the number of students enrolled in the district hosting the charter school. Because of the wide dispersion of school district size, we take the natural log of district enrollment. We used logistic regression to model these relationships; therefore, the odds ratios are presented. Odds ratios are interpreted as the increase in the likelihood of having a theme (vs. not having a theme) if the odds ratio is greater than one, and a decrease in the likelihood for an odds ratio of less than one.

As indicated, the simple differences in themes observed across the types of

AUGUST 2005 


\section{Influence of Founder Type on Charter Schools}

charter schools are not statistically significant when controls are included for central city status, years of operation, and size of the home district. The greater tendency for schools started by local business organizations to offer curricular themes receives some support, but the fact that the Wald chi-square statistic does not achieve statistical significance means that we must treat even this limited finding of differences as tentative. Comparable multivariate analyses of targeting (not shown for reasons of space) also failed to reveal significant differences either between EMO- and non-EMO-initiated charters or among the various mission-oriented schools.

Another way in which charter schools may position themselves in the market is through the grade structure they offer. Because high schools are under strong demand pressure to provide various expensive facilities and services - to accommodate interscholastic sports, science labs, advanced placement classes, and the like - most analysts agree that high school students are more expensive to educate on a per pupil basis. But most states do not adjust their per-pupil funding proportionally (Nelson et al. 2000). ${ }^{9}$ Presumably, then, market-oriented charter schools will be more reticent to include high school grades. Missionoriented schools, which may, for example, feel compelled to serve older students who are in the greatest danger of dropping out, or which may be pressured to expand to higher grades to accommodate the demands of the community- and school-based groups that were their founders, could be expected to be less sensitive to these marginal cost issues and in some instances propelled by their altruistic impulses to take on that clientele precisely because they present greater problems.

The results of our multivariate analysis (table 4) confirm that charter schools initiated by mission-oriented organizations are more likely to offer high school grades, compared with EMO-only schools. New independent variables introduced here include two previously used as dependent variables (having a theme and targeting) because we expect that they influence a school's decision regarding grade structures. Targeting appears to be important in explaining the structure that charter schools will take. The odds ratio on the targeting variable suggests that schools that target students are more likely to offer high school grades. In the reduced model, the odds ratio on EMO-only or EMO-mix founders is 2.74, suggesting that schools with these founders are almost three times as likely not to offer high school grades currently.

We also looked at whether school leaders expected to offer high school grades in the next three years and find the same pattern as above. In the full version, schools founded by local business, educators, social service organizations, and parents or community groups are significantly more likely to project that they will be offering high school grades in three years. In the reduced model, EMO or EMO-mix founders were much more likely to say that they do not expect to be offering high school grades in three years. Indeed,

\section{American Journal of Education}




\section{Henig et al.}

with an odds ratio of 3.00 , they are three times as likely not to project to offer high school grades in three years than are charter schools with other founders. Here again, the targeting variable is important and predicts that schools that target are more likely to expect to offer high school grades in three years.

\section{Scale of Operation}

Early proponents of charter schools envisioned them as intimate communities in which students would get more individualized attention and teachers would be able to feel more like a cohesive team (Kolderie 1990; Nathan 1991). And the evidence to date has tended to confirm that charter schools are substantially smaller in scale than the traditional public schools with which they compete. Anderson et al. (2000), for instance, reported that charter schools had a median enrollment of 137 compared with 475 in traditional public schools. Because market-oriented schools may be more concerned about achieving economies of scale, however, we expect that the vision of intimate communities may be more accurate when applied to mission-oriented than EMO-initiated charter schools.

In table 5 we examine the question of whether different types of school founders influence the choice of how large a school to open. The size of the student body, or number of students, at the time of the survey is modeled using OLS regression with robust standard errors as a function of a number of independent variables. We use the size of the current student body because we are interested in how the founding situation affects choices and behaviors not just at the time of founding but also whether these initial differences in founding situations result in differences that remain. We expect that whether a school chooses to emphasize a theme or target student populations may also have some bearing on this decision, so we use the dependent variables in the above analysis as control variables here.

As table 5 indicates, the type of founder does appear to influence charter school decisions about how large to be. The sharpest distinction is between schools initiated by EMOs and all others. Compared with those with EMO founders, charter schools launched by more mission-oriented organizations are much smaller. Schools founded by parents or the community are especially small, enrolling on average 221 fewer students than the average EMO-initiated school, suggesting that when these groups set out to establish a school, they are probably looking to create a school that only provides education services to children in the neighborhood. Indeed, every category of mission-oriented founding category has schools that are significantly smaller than EMO-only schools, with the smallest difference being 145 fewer students.

The significant coefficients on some of the control variables are interesting

AUGUST 2005 


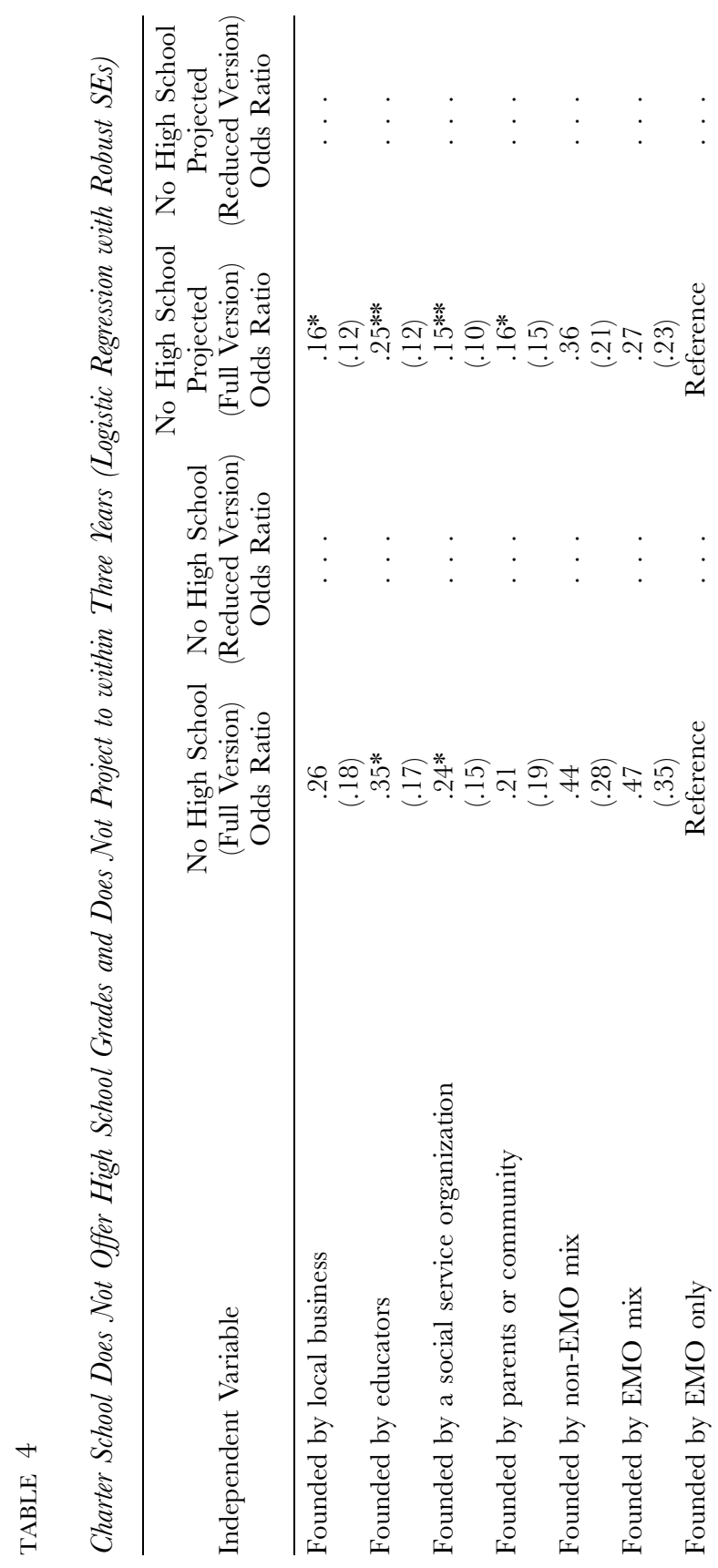

506

This content downloaded from 129.008.122.086 on September 01, 2016 14:09:42 PM

All use subject to University of Chicago Press Terms and Conditions (http://www.journals.uchicago.edu/t-and-c). 


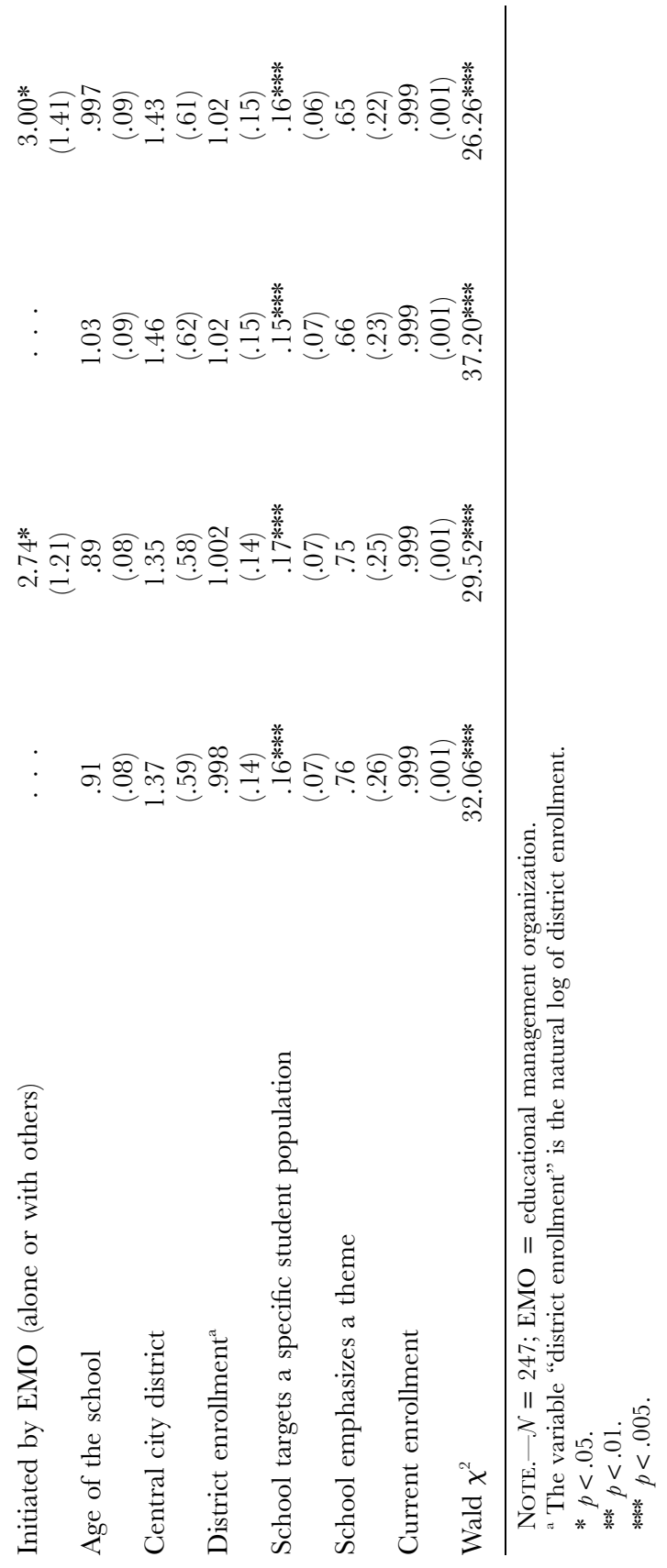

507

This content downloaded from 129.008.122.086 on September 01, 2016 14:09:42 PM

All use subject to University of Chicago Press Terms and Conditions (http://www.journals.uchicago.edu/t-and-c). 


\section{Influence of Founder Type on Charter Schools}

TABLE 5

Size of Student Body (OLS Regression with Robust SE)

\begin{tabular}{|c|c|c|}
\hline Independent Variable & $\begin{array}{c}\text { Student } \\
\text { Population } \\
\text { Size (Full } \\
\text { Model) }\end{array}$ & $\begin{array}{c}\text { Student } \\
\text { Population } \\
\text { Size (Reduced } \\
\text { Model) }\end{array}$ \\
\hline Founded by local business & $\begin{array}{c}-185.93^{* * * *} \\
(66.09)\end{array}$ & . . \\
\hline Founded by educators & $\begin{array}{c}-170.16^{* * * *} \\
(33.14)\end{array}$ & $\cdots$ \\
\hline Founded by a social service organization & $\begin{array}{c}-166.26 * * * \\
(49.59)\end{array}$ & . . \\
\hline Founded by parents or community & $\begin{array}{c}-220.95^{* * * *} \\
(42.97)\end{array}$ & . . \\
\hline Founded by non-EMO mix & $\begin{array}{c}-145.992^{* * * *} \\
(47.42)\end{array}$ & . . \\
\hline Founded by EMO mix & $\begin{array}{c}123.73 \\
(114.20)\end{array}$ & . . \\
\hline Founded by EMO only & Reference & \\
\hline Initiated by EMO (alone or with others) & . . & $\begin{array}{l}241.23^{* * * *} \\
(48.98)\end{array}$ \\
\hline Age of the school (years) & $\begin{array}{l}30.45 * * * \\
(8.38)\end{array}$ & $\begin{array}{l}29.69 * * * \\
(8.52)\end{array}$ \\
\hline Central city district & $\begin{array}{c}-109.59^{* * *} \\
(34.67)\end{array}$ & $\begin{array}{c}-115.18 * * * \\
(34.22)\end{array}$ \\
\hline No. of students in host district & $\begin{array}{l}33.74^{* * *} \\
(10.88)\end{array}$ & $\begin{array}{l}38.40^{* * * *} \\
(10.96)\end{array}$ \\
\hline School targets a population & $\begin{array}{c}-106.60 * * * \\
(25.35)\end{array}$ & $\begin{array}{c}-94.17 * * * \\
(24.38)\end{array}$ \\
\hline School has a theme & $\begin{array}{l}-1.77 \\
(28.30)\end{array}$ & $\begin{array}{r}-11.28 \\
(28.27)\end{array}$ \\
\hline Constant & $\begin{array}{c}29.60 \\
(107.31)\end{array}$ & $\begin{array}{r}-171.82 \\
(107.00)\end{array}$ \\
\hline $\begin{array}{l}F \text {-test statistic } \\
R^{2}\end{array}$ & $\begin{array}{l}6.84^{* * *} \\
.28\end{array}$ & $\begin{array}{l}8.48^{* * * *} \\
.28\end{array}$ \\
\hline
\end{tabular}

Note. $-\mathcal{N}=247 ;$ OLS $=$ ordinary least squares; EMO = educational management organization. Robust standard errors and weighted by state population of charter schools.

*** $p<.005$.

as well. Schools that have been around longer are likely to be larger; this is no surprise, but it does suggest that early findings about the relatively small size of charter schools compared with traditional public schools may have to be revisited in a few years to see the extent to which that finding holds once the fledgling charter schools have built up to their steady-state scale of operation. Charter schools in districts serving higher numbers of students tend

\section{American Journal of Education}


Henig et al.

to be larger, but once that is taken into account, central city charter schools are more likely to be smaller in size. Schools that target a particular population also tend to be smaller; this may partly result from the fact that many of these schools currently focus on a high-need population that presumably is small, or they choose to be small because of the nature of the services they offer. However, charter schools that target groups other than at-risk students also tend to be small, so the link may reflect a general association between targeting and small scale regardless of the specific needs of the targeted population. ${ }^{10}$

\section{Marketing and Market Research}

We also asked each responding school to list if they regularly, occasionally, or never used any of a list of advertising and promotional methods in the recruitment of new students. Economic theories lead us to expect EMO- and business-related charter schools to recruit more aggressively than those motivated more by a professional-, service-, or community-based mission. The pursuit of a profit margin, as we have already indicated, normally pushes firms to seek a larger base of customers. We have already demonstrated that EMO-related charter schools in our sample are larger. This is not to say that mission-oriented schools do not seek to aggressively recruit; those that are animated by a fervent desire to change the lives of children - either through exposing them to different values or a richer academic content - may hope to "convert" as many as possible. Nonetheless, mission-oriented organizations often depend on maintaining a smaller, more intimate community and may be more likely to recruit through informal channels. They are also more likely to lack the management expertise and capital to allow them to grow rapidly, further encouraging a modest and informal recruitment approach. We would expect parent- and community-based charters to be especially likely to limit recruitment to more localized and informal arenas.

Table 6 shows the different methods of advertising and recruiting used by the different types of charter schools, and it provides some evidence that EMOinitiated charter schools may be more likely to use more expensive strategies like paid advertisements (including ones on radio) and Web sites. These schools appear no less likely than others to rely on informal and cheaper options like word of mouth or flyers. We expected community-based organizations to be the most likely to rely on such informal and lower cost practices as open houses, but EMO- and local-business-related schools are among the most likely to say that they use open houses as a recruitment tool.

As an indicator of overall aggressiveness in marketing, we looked at whether schools reported employing three or more of these strategies. The EMO-onlyinitiated schools are the only ones to average the regular use of three or more

AUGUST 2005 


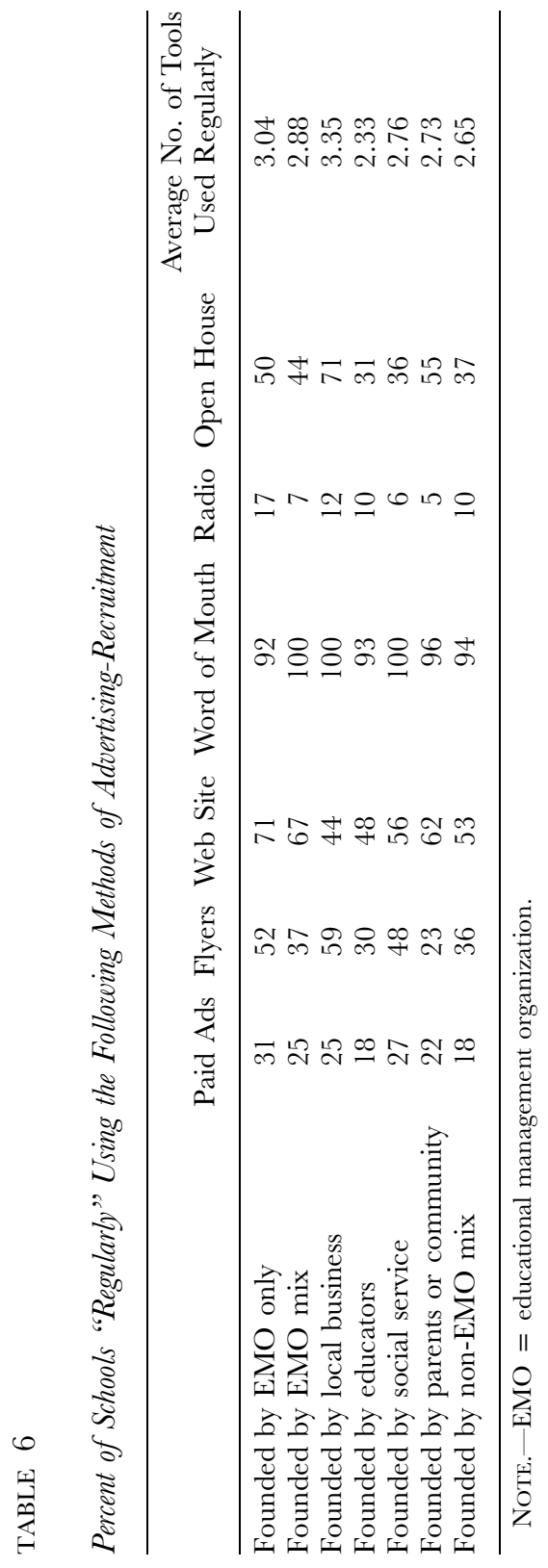

This content downloaded from 129.008.122.086 on September 01, 2016 14:09:42 PM All use subject to University of Chicago Press Terms and Conditions (http://www.journals.uchicago.edu/t-and-c). 
Henig et al.

TABLE 7

Charter Schools Marketing and Recruitment

\begin{tabular}{|c|c|c|}
\hline & $\begin{array}{c}\text { Three or More } \\
\text { Marketing Tools } \\
\text { Used (Full Model) } \\
\text { Odds Ratio }\end{array}$ & $\begin{array}{c}\text { Three or More } \\
\text { Marketing Tools } \\
\text { Used (Reduced Model) } \\
\text { Odds Ratio }\end{array}$ \\
\hline Founded by local business & .51 & . . \\
\hline Founded by educators & $.21 * *$ & . . . \\
\hline $\begin{array}{l}\text { Founded by a social service } \\
\text { organization }\end{array}$ & .74 & . \\
\hline Founded by parents or community & .45 & $\ldots$ \\
\hline Founded by non-EMO mix & $.21^{*}$ & $\ldots$ \\
\hline Founded by EMO mix & $.12^{*}$ & . . \\
\hline Founded by EMO only & Reference & . . \\
\hline $\begin{array}{l}\text { Initiated by EMO (alone or with } \\
\text { others) }\end{array}$ & & 2.07 \\
\hline Age of the school & 1.11 & 1.13 \\
\hline Central city district & .65 & .64 \\
\hline District enrollment ${ }^{\mathrm{a}}$ & 1.23 & 1.21 \\
\hline $\begin{array}{l}\text { School targets a specific student } \\
\text { population }\end{array}$ & 1.36 & 1.46 \\
\hline School emphasizes a theme & 1.61 & 1.50 \\
\hline Current enrollment & 1.001 & 1.001 \\
\hline Wald $\chi^{2}$ & $21.76^{*}$ & 8.82 \\
\hline
\end{tabular}

NOTE.-EMO = educational management organization.

a The variable "district enrollment" is the natural log of district enrollment.

$* p<.05$.

$* * p<.01$.

tools, and we test whether the differences between them and the various mission-oriented categories are significant. Table 7, which presents the multivariate analysis, shows that schools initiated by educators are significantly less likely to employ multiple recruitment strategies. There are several possible explanations. Some critics of the professional education community suggest that a history of monopoly status combined with a professional ethos that celebrates their own expertise have led teachers to adopt a "take it or leave it" attitude toward consumers; if deeply enough ingrained, such an orientation might even be carried by the presumably more entrepreneurial subset that has self-consciously opted to move to the more market-sensitive arena of charter schools. More likely, perhaps, is the possibility that, because they often are headed by principals and teachers already familiar to the local community, educator-initiated schools may feel less of a need to advertise. Schools founded by a mix of partners (whether or not including an EMO) are also significantly

AUGUST 2005 


\section{Influence of Founder Type on Charter Schools}

less likely than EMO-only-initiated charters to use three or more marketing tools.

Our final set of analyses relates to the kinds of information charter schools collect about consumer demand (student and parent surveys) and supply-side competitors. Market theories project that charter schools should be attuned to what parents and students - current and prospective - are looking for, and regularly conducting surveys and interviews would be logical ways to do so. Just as private firms in other markets scout out their competition, it also makes sense to expect charter schools to devote some effort to monitoring activities among theirs. In general, we would expect EMO-related firms to be the most inclined to engage in such market research, with educators - for reasons alluded to above - perhaps the least. To our knowledge, there has been little study or even much speculation about whether charter schools define their competition as consisting primarily of public schools, other charter schools, or private schools. Based on the supposition that EMO-related charter schools might be aiming at a more upscale and mobile consumer group, we anticipate that they would be more likely than the others to monitor private and charter schools.

Table 8 provides basic descriptive information on the market research behavior of different types of charter schools. The patterns are erratic and, for the most part, confound our expectation. The EMO-related schools, particularly those with an EMO as their sole founder, were among the least likely to collect demand-side data systematically, either from current or prospective students and parents. There is a possibility that whatever market research is being done is carried out at the central corporate level, rather than at the school level where our information was collected. Local-business-initiated charters were the most likely to engage in both demand- and supply-side research. Charter schools started by social service or nonprofit groups closely monitored their current consumer populations but were as disinterested as the EMO charters in surveying prospective students and parents. The EMO schools also were relatively disinterested in monitoring the competition, which surprised us, but to the extent that they did pay attention, they were more likely than other types of charter schools to look at private schools and least likely to monitor the conventional public schools. As on the demand side, local-business-initiated charters appeared most attuned to market research.

The multivariate analysis indicates that larger schools generally are more likely to engage in demand-side data gathering with parents of currents students, which is presumably a function of more slack resources associated with economies of scale on the staffing side. The tendency of local-business-initiated charters to be more aggressive holds for surveying parents of current students, but other variables are not significant. It appears that there are not great differences in the marketing and market research behaviors of charter schools.

\section{American Journal of Education}




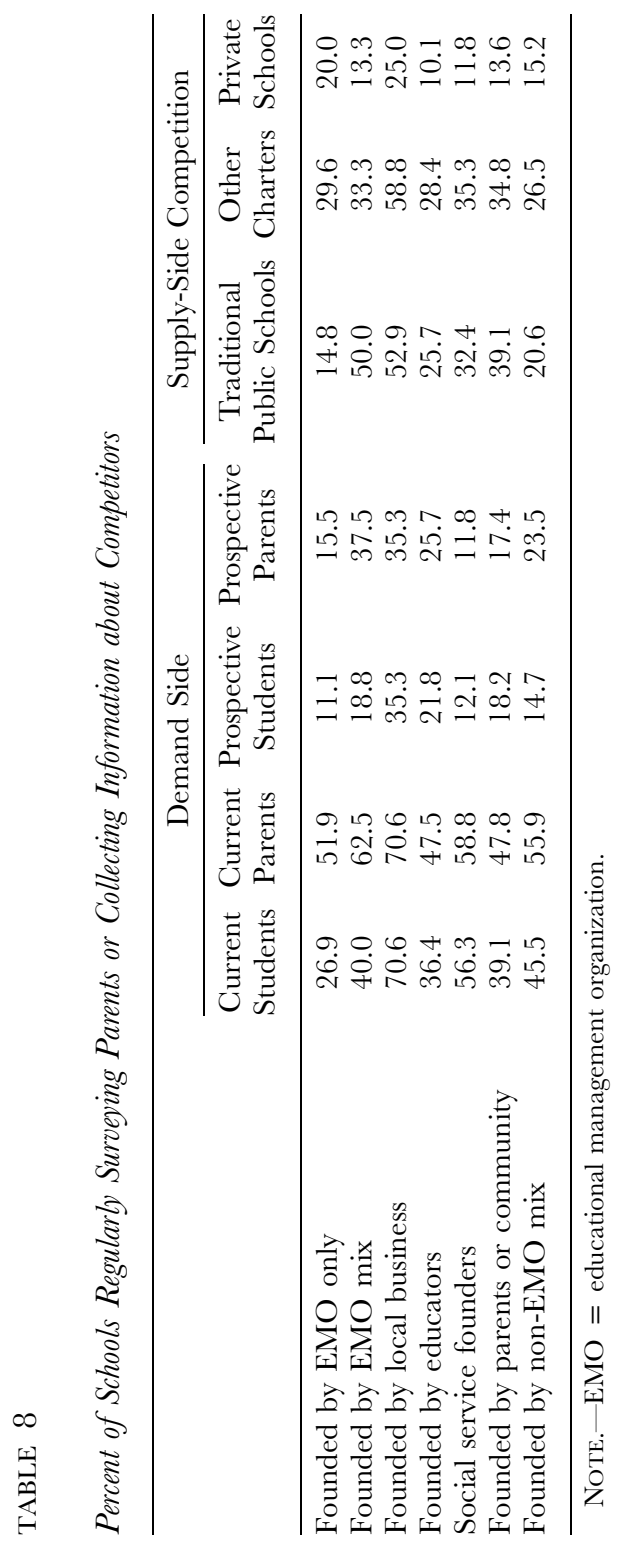

This content downloaded from 129.008.122.086 on September 01, 2016 14:09:42 PM All use subject to University of Chicago Press Terms and Conditions (http://www.journals.uchicago.edu/t-and-c). 


\section{Influence of Founder Type on Charter Schools}

In our field research we heard anecdotal evidence of charters having more demand for their schools than seats available; this oversubscription may mitigate the need for all types of charter schools to recruit and monitor the competition aggressively.

\section{Conclusions: Accounting for Organizational Differentiation and Convergence}

Much of the existing literature on charter schools treats them as an undifferentiated mass. Even those who note that the umbrella term "charter school" encompasses a diverse array of organizations typically have not elaborated theoretically based typologies to impose a more meaningful framework for analyzing the phenomenon. We address this serious gap in the literature by introducing a typology of charter school types grounded in the proposition that the norms, traditions, and perspectives of the founding organization may bear on the kinds of decisions that charter schools make.

What our empirical evidence and statistical tests turn up is a mixed story. In several of the decision arenas that we review here, we find evidence of a sharp distinction between charter schools that have EMOs among their founders and other types of charter schools. Specifically, there is strong evidence, based on multivariate analysis, that EMO-initiated charters are much less likely to include high school grade levels and are likely to be considerably larger than other charter schools. The EMO-initiated charter schools, it appears, may be less likely to target particular subpopulations and more likely to use high-cost marketing strategies. The distinctiveness of EMO-initiated charters may have more to do with their corporate form than the norms and values of the individuals calling the shots, since charter schools launched by local business interests typically behaved more like mission-oriented charter schools. ${ }^{11}$ The EMO-initiated schools were not substantially more likely to aim at a median student, aggressively advertise, engage in market research regarding present or potential customers, or monitor competitors.

That for-profit EMOs may behave differently from other charter schools comports with the evidence emerging from other studies (Brown et al. 2004; Lacireno-Paquet 2004; Lacireno-Paquet et al. 2002; Miron and Nelson 2002). While much of the theoretical case for charters is based on market-laced notions of efficiency, innovation, and competition, much of the political rhetoric aimed to reassure critics relies on anecdotal accounts of mission-oriented schools to emphasize that charter schools will provide nurturing environments and will not place profits over learning or exacerbate social inequities. The efficiency claims of market proponents seem to have credibility when applied to the EMO model, but these may come at the cost of some of the other

\section{American Journal of Education}


Henig et al.

values that matter to the public. To the extent that the EMO model for charters is different, legislators, charter authorizers, and charter regulators may need to develop policy instruments designed to acknowledge such distinctions. This is especially the case in light of the apparent trend toward greater involvement by for-profit EMOs, both as founding partners and as new partners for missionoriented charters that find that they need the capital and management expertise EMOs appear to provide. If these schools gradually muscle aside smaller and frailer mission-oriented schools, some attributes evident in the charter school movement as currently constituted may prove short-lived.

We found fewer and weaker differences among the charters launched by different types of mission-oriented founders. Schools associated with local business organizations were more likely to be organized around a theme, as expected, usually one with a vocational focus. They also appeared to be more likely than EMO-initiated or other mission-oriented schools to advertise and engage in market research aggressively. Schools founded by social service organizations were most likely to target at-risk students, while those founded by parent or community groups were least likely to do so. Schools founded by educators appeared less likely than others to advertise aggressively. That we did not find sharper distinctions in behavior among the subcategories could simply reflect some weaknesses in our sample and design. For example, we make inferences about the motivations of charter founders based on the formal nature of the organizations involved, and it may be that more direct indicators of core values are required. Our response rate, as noted, is not as high as one would like, and, while broadly representative when judged against known parameters of the population, there may be meaningful biases; for example, if more aggressively profit-oriented EMOs or more eccentric mission-oriented charter schools were less likely to respond, our sample might be biased toward a more bland and undifferentiated median.

That said, our findings suggest that, more than we initially envisioned, the external environment and core educational tasks may impose similar patterns of behavior on charter schools regardless of their differing organizational roots. Regardless of the different reasons that founders may choose to charter a school, it may be that the basic task of operating a charter school is relatively uniform and competitive pressures so severe that entrepreneurs adopting novel themes and targeting small, unique populations cannot survive for long. DiMaggio and Anheier, for instance, suggest that "differences in the behavior of [nonprofit] and other firms in the same industry often flow from industry composition . . . e.g. degree of government involvement in regulation etc." (DiMaggio and Anheier 1990, 150). According to this perspective, neither the legal nor the cultural distinctions between nonprofits and for-profits are sharp or strong enough to create distinct patterns of behavior when the groups are operating within the same institutional constraints. What will matter most are

AUGUST 2005 


\section{Influence of Founder Type on Charter Schools}

environmental factors such as the intensity of competition, the particular nature and distribution of consumer demand, the preferences of foundations and other sources of philanthropic support, and the funding and regulatory regimes that state governments create by way of the particular laws they adopt and the manner in which they are implemented. Lubienski (2004, 88), in his recent review, suggests that the failure of charter schools to generate the kinds of innovation that some proponents expected may result from the fact that they are too exposed to market forces; research and innovation are more common, he argues, in organizations that are "shielded from the immediate competitive imperatives to attract and retain customers, to prove the direct value of every idea, or even to stay out of the red."

Adding to this prediction of convergence is the fact that the legal and formal distinctions between for-profits and nonprofits are generally indistinct and permeable. Some organizations led by individuals who are very much motivated by material goals and a market-oriented sense of competition and gain may choose to organize themselves as nonprofits simply to gain a patina of legitimacy or access to certain foundation and government funds restricted to nonprofits by policy; Weisbrod (1998) refers to these as "for-profits in disguise." By the same token, some charter school originators who are motivated primarily by a desire to "do good" may nonetheless opt for a for-profit legal status out of desire to gain greater access to private capital. Some of the leaders within the for-profit EMO community claim that a strong sense of social mission lies behind their involvement in the sector; if this can be taken at face value, these might be considered to be "nonprofits in disguise." Also muddying the distinction between for-profit and nonprofit is the fact that some charter schools that were initiated by mission-oriented nonprofits have subsequently contracted with or otherwise allied with EMOs, and while the originators in principle are still setting the goals of the organization, it is an empirical question whether they may lose control of the reins in such relationships. ${ }^{12}$

Convergence is also possibly shaped or unwittingly encouraged by the regulator and policy environment (Witte et al. 2003; Wohstetter et al. 2004). Charter authorizers, for example, play a key role in accepting and rejecting charter school proposals and thus shape what charter schools look like in each state or jurisdiction. Testing requirements, a feature of all charter school legislation, also may lead to convergence in terms of what schools are teaching and how, even if the organizational structure (for-profit or nonprofit) varies.

Finally, organizational behavior may converge because the "idea" of schooling that has emerged out of professional education and public experience is so uniform and ingrained that innovations and innovators tend to be regarded skeptically and are often marginalized. The hegemonic character of what David Tyack (1974) has called "the one best system" may rest less on the bureaucratic and political monopoly that public educators have used to impose

\section{American Journal of Education}


Henig et al.

their narrow vision than on a nearly universally shared notion of what schools are supposed to look like and do. If that is the case, charter schools, in order to survive, may be forced to behave and look similarly, regardless of their internally generated inclination. ${ }^{13}$ If parents tend to have bland and conventional views of what constitutes a "good education"; if foundations, lenders, and other sources of revenue and credit set fairly narrow conditions for support; if laws and regulations enforce a set of behaviors; or if the practical challenges of structuring an education impose certain solutions, the differences among charter schools might be constrained by or forced to depend on variations in external context, not internal organizational goals.

\section{Notes}

The authors would like to thank the Spencer Foundation for their generous support of this project and the schools in Arizona, the District of Columbia, Michigan, and Pennsylvania that responded to our survey. Elisabeth Clemens, Brayden King, and Melissa Fry (Arizona); Richard Hula and Chelsea Haring (Michigan); and Rebecca Maynard and Connie Keefe (Pennsylvania) provided assistance with the surveys. Katrina Bulkley, Bruce Fuller, Michael Mintrom, David Plank, and Kevin Smith provided valuable feedback on earlier drafts.

1. On professionalism generally, see DiMaggio and Anheier (1990), Freidson (1988), and Kirp (1982). On professionalism and charter schools, see Sykes and Plank (2001).

2. Local business groups often turn to education reform after "cutting their teeth" on more conventional urban revitalization efforts: promoting downtown redevelopment, building convention centers, attracting professional sports teams, and the like (Stone et al. 2001). Reforming the conventional public school system, however, often turns out to be more difficult than they anticipated, and some corporate leaders have turned to charter schools (and other forms of school choice) as a potential way to work around the recalcitrant bureaucracy. For example, in Washington, DC, the business group that, during the late 1980s, sponsored the Committee of Public Education (COPE) and sought to turn around the public school system subsequently threw up its hands, closing down COPE and instead sponsoring a charter school resource center (Henig et al. 1999).

3. In our survey, the responding schools had a mean enrollment of 276 students, comparable with the mean enrollment of 220 in the SASS data set for the same jurisdictions; 62 percent of the schools responding to our survey reported offering a theme, while 56 percent of the SASS charter schools reported that they offered "programs with special instructional approaches." Although the wording in SASS and our survey is not identical, along several important measures the two groups of charter schools surveyed are broadly similar. Our survey asked two slightly different questions about EMO affiliation. The first asked whether the school was "founded by" an EMO (16.3 percent), and the second asked whether the charter school had "collaborated with or received support from" a for-profit EMO (23.3 percent). The SASS asked whether charter schools were "managed by an organization that manages other schools but was not a school district," to which 21.6 percent of the schools in the four jurisdictions responded that they were managed by for-profit EMOs. Since our "collaboration" question may imply a less formal relationship than the "management" wording

AUGUST 2005 


\section{Influence of Founder Type on Charter Schools}

used by SASS, and in light of the fact that our later survey might have been expected to find a higher level of EMO involvement, we conclude that our sample may underrepresent the EMO-associated charter schools to a slight degree. We did find possible differences in grade-level configuration; e.g., 26 percent of the schools in our sample are high schools, a lower percentage than in the SASS population (36 percent).

4. They were presented with the following options and told to check all that applied: converted from a traditional public school, converted from former private school, extension of an existing social service organization, founded by former public school teachers, founded by a for-profit EMO, founded by a group of parents, founded by the local business community, and other (please specify). Of the 253 respondents with codable answers, 49, or slightly fewer than 20 percent, checked more than one option. For those that checked only the "other" category, we examined the name or description of the founding group and recoded the organization, where it was possible, into one of seven categories.

5. Schools formed by public educators include public school conversions, private school conversions, those founded by former public school teachers, and those who checked "other" but indicated that they were formed by private school teachers or administrators. Schools formed by social service or nonprofit organizations include those formed as an extension of an existing social service organization and those that checked "other" but listed a nonprofit organization, religious institution, or religious leader. Schools formed by community and parent groups include those founded by a group of parents and those that checked "other" but indicated that they were formed by "a community organization," a "community-based organization," or a particular community organization. Schools founded by local business groups include those that checked "other" but listed particular corporations or local business sponsors. We expect multisponsor organizations to behave more like the other mission-oriented schools than those associated with EMOs, but we have no a priori expectations about whether they would resemble one type of mission orientation over others.

6. The 5 percent figure understates EMO penetration in the District of Columbia in at least a couple of ways. None of the Edison Schools in the District of Columbia responded to our survey (Edison Schools did respond elsewhere), and two other schools that have had EMOs as major partners from the beginning nonetheless did not mention them among the founders. We know this because we have been following the the District of Columbia charter school situation carefully and have conducted interviews at these schools. We chose not to recode these schools here, since we do not have comparable depth of knowledge about the situations in other states.

7. We matched schools to their census area using the common core of data, which defines its metropolitan service code 1 category as comprising districts that primarily serve a central city of a metropolitan service area. This is the variable that we use in our statistical models.

8. The difference is significant only at the .07 level.

9. Arizona and the District of Columbia do adjust their funding; Michigan and Pennsylvania do not, according to Nelson et al. (2000). In the District of Columbia, ironically, the per-public reimbursement formula is actually lower at the high school level.

10. Another dimension related to scale involves whether schools have, or envision having, multiple campuses. Our analysis (not shown) found that none of the foundertype variables had a statistically significant effect on this decision among founder types in the sense that the distinctions do not matter. Older schools were more likely to have two or more campuses. Schools emphasizing a target or curricular themes were more likely to project expanding to two or more campuses within three years.

\section{American Journal of Education}


11. That may result from the fact that these local business groups frame their involvement in terms of a collective good - improving the environment for economic development - rather than profit maximization. But it is also possible that it reflects a tendency by such groups to turn over administration of the schools they sponsor to individuals whose roots lie in education and the nonprofit sector.

12. Rather than look at the nature of the founding organizations, we could have opted to build our typology based on whether charter schools are currently linked to EMOs. In this analysis, though, we were particularly interested in the question of whether the differences in founder's organizational traditions and norms would continue to shape the schools' behavior regardless of whether they later find it more practical to seek EMO services. It is an important question, though, whether missionoriented charter schools lose their distinctive character when they subsequently ally with EMOs, and this is something that we hope to explore further in future analyses.

13. This is a specific application of Meyer and Rowan's (1977) observation that organizations may adapt to environmental niches based less on technical pressures than on a reflection of socially constructed reality.

\section{References}

Allen, Jeanne, and Anne Varghese Marcucio. 2004. "Charter Schools Laws across the States: Ranking and Scorecard, 8th Edition." Center for Education Reform, Washington, DC, http://www.edreform.com/_upload/charter_school_laws.pdf.

Anderson, Lee, Nancy Adelman, Kara Finnegan, Lynyonne Cotton, Mary Beth Donnelly, and Tiffany Price. 2000. "The State of Charter Schools 2000: Fourth Year Report." Office of Educational Research and Improvement, U.S. Department of Education, Washington, DC.

Berry, Jeffrey M. 1999. The New Liberalism. Washington, DC: Brookings Institution.

Brown, Heath, Jeffrey R. Henig, Thomas T. Holyoke, and Natalie Lacireno-Paquet. 2004. "Scale of Operations and Locus of Control in Market- vs. Mission-Oriented Charter Schools." Social Science Ouarterly 85 (December): 1035-51.

Bulkley, Katrina. 2001. "Balancing Act: Educational Management Organizations and Charter School Autonomy." In Taking Account of Charter Schools, ed. Katrina Bulkley and Priscilla Wohlstetter. New York: Teachers College Press.

Bulkley, Katrina. 2002. "Recentralizing Decentralization? Educational Management Organizations and Charter Schools' Educational Programs." Occasional Paper 60, National Center for the Study of Privatization in Education, Teachers College, New York.

Bushouse, Brenda K. 1999. "Motivations of Nonprofit and For-Profit Entrepreneurs in the Child Care Industry: Implications for Mixed Industries." Paper presented at the annual conference of the Association for Research on Nonprofit Organizations and Voluntary Action, Arlington, VA.

Center for Education Reform. 2002. "Ranking the State Charter Law, Center for Education Reform." Center for Education Reform, Washington, DC, http://www .edreform.com/.

DiMaggio, Paul J., and Helmut K. Anheier. 1990. "The Sociology of Nonprofit Organizations and Sectors." Annual Review of Sociology 16 (August): 137-59.

Erickson, Robert, Gerald Wright, and John McIver. 1993. Statehouse Democracy. Cambridge: Cambridge University Press.

AUGUST 2005 


\section{Influence of Founder Type on Charter Schools}

Finn, Chester E., Jr., Bruno Mano, and Gregg Vanourek. 2000. Charter Schools in Action. Princeton, NJ: Princeton University Press.

Fiske, Edward B., and Helen F. Ladd. 2000. When Schools Compete: A Cautionary Tale. Washington, DC: Brookings Institution.

Freidson, Eliot. 1988. Professional Powers: A Study of the Institutionalization of Formal Knowledge. Chicago: University of Chicago Press.

Fuller, Bruce, Marytza Gawlik, Emliel K. Gonzales, and Sandra Park. 2003. "Charter School and Inequality: National Disparities in Funding, Teacher Quality, and Student Support." Working Paper Series 03-2, PACE Center, Berkeley.

Fuller, Bruce, Marytza Gawlik, Emliel K. Gonzales, and Sandra Park. 2004. "Localized Ideals of Fairness: Inequality among Charter Schools." In Taking Account of Charter Schools, ed. Katrina Bulkley and Priscilla Wohlstetter. New York: Teachers College Press.

Henig, Jeffrey R., Thomas T. Holyoke, Natalie Lacireno-Paquet, and Michele Moser. 2003. "Privatization, Politics, and Urban Services: The Political Behavior of Charter Schools." Zournal of Urban Affairs 25 (February): 37-54.

Henig, Jeffrey R., Richard C. Hula, Marion Orr, and Desiree Pedescleaux. 1999. The Color of School Reform. Lawrence: University Press of Kansas.

Henig, Jeffrey R., and Jason MacDonald. 2002. "Locational Decisions of Charter School: Probing the Market Metaphor." Social Science Ouarterly 83 (December): 962-80.

Hero, Rodney E. 1998. Faces of Inequality: Social Diversity in American Politics. New York: Oxford University Press.

Hess, Frederick, Robert Maranto, and Scott Milliman. 2001. "Small Districts in Big Trouble: How Four Arizona School Systems Responded to Charter Competition." Teachers College Record 103 (6): 1102-24.

Katz, Michael B. 1996. In the Shadow of the Poorhouse: A Social History of Welfare in America. 10th anniversary ed. New York: Basic.

Kettl, Donald F. 1993. Sharing Power: Public Governance and Private Markets. Washington, DC: Brookings Institution.

Kirp, David L. 1982. "Professionalization as a Policy Choice: British Special Education in Comparative Perspective." World Politics 34 (2): 137-74.

Kolderie, Ted. 1990. Beyond Choice to New Public Schools: Withdrawing the Exclusive Franchise in Public Education. Washington, DC: Progressive Policy Institute.

Lacireno-Paquet, Natalie. 2004. "Do EMO-Operated Charter Schools Serve Disadvantaged Students? The Influence of Policy." Education Policy Analysis Archives 12 (June), http://epaa.asu.edu/epaa/v12n26/.

Lacireno-Paquet, Natalie, Thomas T. Holyoke, Jeffrey Henig, and Michele Moser. 2002. "Creaming versus Cropping: Charter School Enrollment Practices in Response to Market Incentives." Educational Evaluation and Policv Analvsis 24 (Summer): 145-58.

Linowes, David F. 1988. Privatization: Toward More Effective Government. Urbana: University of Illinois Press.

Lubienski, Christopher. 2004. "Charter School Innovation in Theory and Practice: Autonomy, R\&D, and Curricular Conformity." In Taking Account of Charter Schools, ed. Katrina Bulkley and Priscilla Wohlstetter. New York: Teachers College Press.

Mark, Tami L. 1995. "Psychiatric Hospital Ownership and Performance: Do Nonprofit Organizations Offer Advantages in Markets Characterized by Asymmetric Information?" Gournal of Human Resources 31 (3): 631-49.

Mark, Tami L. 1998. "Analysis of the Rationale for, and Consequences of, Nonprofit and For-Profit Ownership Conversions." Health Services Research 34 (April): 83-101.

\section{American Journal of Education}


Meyer, John W., and Brian Rowan. 1977. "Institutionalized Organizations: Formal Structure as Myth and Ceremony." American fournal of Sociology 83 (2): 340-63.

Miron, Gary, and Christopher Nelson. 2002. What's Public about Charter Schools: Lessons Learned about Choice and Accountability. Thousand Oaks, CA: Corwin.

Nathan, Joseph. 1991. Free to Teach: Achieving Equity and Excellence in Schools. New York: Pilgrim.

Nelson, F. Howard, Edward Muir, and Rachel Drown. 2000. "Venturesome Capital: State Charter School Finance Systems." Office of Educational Research and Improvement, U.S. Department of Education, Washington, DC.

Peterson, Paul E. 1981. City Limits. Chicago: University of Chicago Press.

Rothstein, Richard. 1998. The Way We Were? New York: Century Foundation.

Salamon, Lester. 1987. "Partners in Public Service: The Scope and Theory of Government-Nonprofit Relations." In The Nonproft Sector, ed. Walter W. Powell. New Haven, CT: Yale University Press.

Salamon, Lester. 1995. Partners in Public Service: Government-Nonprofit Relations in the Modern Welfare State. Baltimore: Johns Hopkins University Press.

Savas, E. S. 2000. Privatization and Public-Private Partnerships. New York: Chatham House.

Smith, Stephen R., and Michael Lipsky. 1993. Nonprofits for Hire: The Welfare State in the Age of Contracting. Cambridge, MA: Harvard University Press.

Solomon, Lewis G., Michael K. Block, and Mary Gifford. 1999. "A Market-Based Education System in the Making." Center for Market-Based Education, Phoenix, http://www.azschoolchoice.orgs/pubs/06.htm.

Stone, Clarence N., Jeffrey R. Henig, Bryan D. Jones, and Carol Pierannunzi. 2001. Building Civic Capacity: The Politics of Reforming Urban Schools. Lawrence: University Press of Kansas, 2001.

Sykes, Gary, and David N. Plank. 2001. "Populists and Professionals: Alternatives to School Reform." Paper presented at CPRE Educational Issues on Charter Schools Conference, Washington, DC, November.

Teske, Paul, Mark Schneider, Jack Buckley, and Sara Clark. 2000. "Does Charter School Competition Improve Traditional Public Schools?" Manhattan Institute's Civic Report 10, Center for Givic Innovation, Manhattan Institute, New York.

Tyack, David. 1974. The One Best System. Cambridge, MA: Harvard University Press.

Vergari, Sandra. 2002. "Charter School Boards: A Governance Model for Traditional Public Schools?" Paper presented at the annual meeting of the American Political Science Association, Boston, August 28-September 1.

Weisbrod, Burton A. 1998. "Institutional Form and Institutional Behavior." In Private Action and the Public Good, ed. Walter W. Powell and Elisabeth S. Clemens. New Haven, CT: Yale University Press.

Wilson, James Q. 1973. Political Organizations. New York: Basic.

Witte, John F., Arnold F. Shober, and Paul Manna. 2003. "Analyzing State Charter School Laws and Their Influence on the Formation of Charter Schools in the United States." Paper prepared for the annual meeting of the American Political Science Association, Philadelphia.

Wohlstetter, Priscilla, Courtney L. Malloy, Joanna Smith, and Guilbert Hentschke. 2004. "Incentives for Charter Schools: Building School Capacity through CrossSectoral Alliances." Educational Administration Ouarterlv 40 (August): 321-65.

Wong, Kenneth, and Francis Shen. 2000. "Institutional Effects of Charter Schools: Competition, Innovation, and Segregation." Paper presented at the American Political Science Association, Washington, DC.

Zimmer, Ron, Richard Buddin, Derrick Chau, Glenn Daley, Brian Gill, Cassandra Guarino, Laura Hamilton, Gathy Krop, Dan McCaffrey, Melinda Sandler, and

AUGUST 2005 


\section{Influence of Founder Type on Charter Schools}

Dominic Brewer. 2003. "Charter School Operations and Performance: Evidence from California." RAND, Santa Monica, CA.

Zollers, Nancy J., and Arun K. Ramanathan. 1998. "For-Profit Charter Schools and Students with Disabilities: The Sordid Side of the Business of Schooling." Phi Delta Kappan 79:297-304. 